\title{
The climatic environment of the Carnarvon Basin, Western Australia
}

\author{
Karl-Heinz Wyrwoll', Joseph Courtney ${ }^{2}$ and Peter Sandercock ${ }^{1}$ \\ 'Department of Geography, The University of Western Australia, Nedlands, \\ Western Australia 6907, Australia \\ ${ }^{2}$ Bureau of Meteorology, 1100 Hay Street, West Perth, Western Australia 6005, Australia
}

\begin{abstract}
We discuss aspects of climate, both past and present, as important geographical controls on ecological structuring and evolution in the Carnarvon Basin. Attention is drawn to the variability inherent in the region's climate, and its strong drought 'signature'. Future climates may well differ from the contemporary climatic regime, but it is too early for regional projections.
\end{abstract}

\section{INTRODUCTION}

The Carnarvon Basin is on the mid-west coast of Western Australia, and extends inland to $115^{\circ} 30^{\prime} \mathrm{E}$ longitude. This paper outlines aspects of the Basin's climate that are relevant to the aims of biological survey work carried out by Burbidge et al. (2000) between $24^{\circ} \mathrm{S}$ and $27^{\circ} 30^{\prime} \mathrm{S}$. Climate, climate variability and climate change form an integral part of the study area's environmental setting.

It was outside the scope of the project to establish climate/microclimate monitoring sites at the sample site locations. Instead, the available regional-scale climate observation network was used. The region is served by a number of stations for which reliable records of some of the important climate parameters are available. Given that much of the climate of the study area is characterised by aridity, with the mean annual evaporation being more than an order of magnitude higher than the precipitation received, precipitation is a climate parameter which is of fundamental importance to the aims of the biological survey. And while the network of precipitation sites is sufficient to capture the regional variability that exists in the precipitation patterns, this is not the case for the other climatic parameters. To overcome this problem, it is now customary in biological surveys to use BIOCLIM routines, which are meant to provide an overall impression of regional climate characteristics of specific relevance to biological work.

BIOCLIM uses data obtained from the Australian Bureau of Meteorology to interpolate a set of climatic surfaces. The interpolation technique is described by Wahla and Wendelberger (1980). Australia-wide temperature surfaces were fitted to measured data from 901 stations. Precipitation surfaces were fitted to data from a total of c. 11000 stations for the period 1901-1975 and with a minimum length of record of 5 years (Busby, 1991).
Mathematical routines in BIOCLIM generate a set of bioclimatic parameters which summarise annual and seasonal mean conditions, extreme values and intra-year seasonality. The parameters are derived from mean monthly climate estimates, so as to approximate energy and water balances at a given location (Nix, 1986). For example, annual mean temperature and annual mean precipitation provide a gross approximation of total energy and water inputs at a site. Highest and lowest monthly mean values provide a measure of seasonal extremes and allow computation of annual range. Mean temperatures and precipitation of wettest and driest successive three month periods (wettest and driest quarters) provide a measure of conditions prevailing during potentially active and dormant seasons ( $\mathrm{Nix}, 1986$ ).

It should be noted that there are major limitations in using BIOCLIM in regions with high spatial climate variability and a limited number of climate stations. Furthermore, the length of the record used must be sufficient to capture the inherent variability of the climate parameter considered, and this may not always be possible. Both considerations impose significant limitations on the 'validity' and usefulness of the surfaces generated. Isoline maps of the BIOCLIM surfaces used in this study are provided in Appendix 1.

\section{BROAD-SCALE CLIMATIC CONTROLS}

The Carnarvon Basin lies in a transitional climatic region, affected by the winter rainfall - winter circulation of the south of Western Australia, and the summer rainfall - monsoonal regime of the north. Maximum daily temperatures are high for much of the year, and extreme during the summer months. The Koeppen classification describes much of the region as BWh (arid; mean annual 
temperature above $18^{\circ} \mathrm{C}$ ) and the extreme southern part of the region as BSsh (semi-arid; wettest winter month receives at least three times as much rain as the driest summer month; mean annual temperature above $18^{\circ} \mathrm{C}$ ).

The dynamic climatology of the region is dominated by the Sub-Tropical High Pressure Cell (STH) and the westerly-Rossby regime of the south. The high pressure ridge lies to the south of the region for much of the year, directing an easterly flow across it. With the northward movement of the high pressure ridge during the winter months, the region lies at the northern margins of the winter rainfall regime. The northern tropical-summer monsoon regime influences the region to a much more limited extent.

During the summer months a low pressure trough can develop within the easterlies - the West Coast Trough. The development of the summer trough, which is associated with the presence of the Pilbara Heat Low, brings unstable conditions to the region. Convergence of moist air in the trough often results in thunderstorm activity. Tropical lows associated with the monsoonal regime can move southward into the region bringing significant rainfall to the region. Tropical cyclones which affect the region are capable of generating extreme winds and intense rainfall.

Northwest Australian 'cloud bands' (Tapp and Barrell, 1984) are a feature of some importance. These cloud bands often originate in the east Indian Ocean near Indonesia as deep convective clouds. They consist primarily of stratiform cloud, which gradually attains a greater height as it extends further south (Tapp and Barrrel, 1984; Sturman and Tapper, 1996), to traverse the Australian continent in a northwest - southeast direction. The majority of cloud bands occur between April and September. The cloud bands are associated with a mid-latitude trough which extends into low latitudes.

The dominance of the STH and the generally dry easterly regime over the region for much of the year results in low levels of cloud cover, high sunshine duration and high amounts of incident solar radiation. Average daily global radiation (incident and diffuse) at Carnarvon ranges from $12 \mathrm{MJ} / \mathrm{m}^{2}$ in June to $32 \mathrm{MJ} / \mathrm{m}^{2}$ in December. The average number of hours of sunshine per day in the south of the study area varies from 11 in December and January to less than 7 in June and July. Corresponding values in the north range from about 11 in October to about 8 in May and July. The overall energy balance is likely to be negative for much of the region. The high Bowen Ratio (sensible heat loss to atmosphere/latent heat loss to atmosphere) and the high average daily global radiation amounts received for much of the year, imply a strong transfer of sensible heat. This is reflected in the high temperatures experienced during the summer months and the relatively high daytime temperatures during the winter.

A significant difference is to be expected in the climatic conditions of the coastal survey sites and those located further inland. Minimum (maximum) temperatures are generally higher (lower) in the coastal areas. The atmospheric moisture content is generally higher in the coastal areas. Strong southsouth-westerly winds influence the climate of the coastal region for much of the year, and are especially prominent in the summer months.

\section{CLIMATE PARAMETERS}

\section{Precipitation}

Median annual precipitation ranges from $200 \mathrm{~mm}$ in the northern part of the study area to $400 \mathrm{~mm}$ in its southern parts (Figure 1). The major rain producing mechanisms in the study area are :

- Events associated with northwest Australian cloud bands, often acting in association with frontal systems. The resultant baroclinicity may give rise to heavy rain falling over a wide

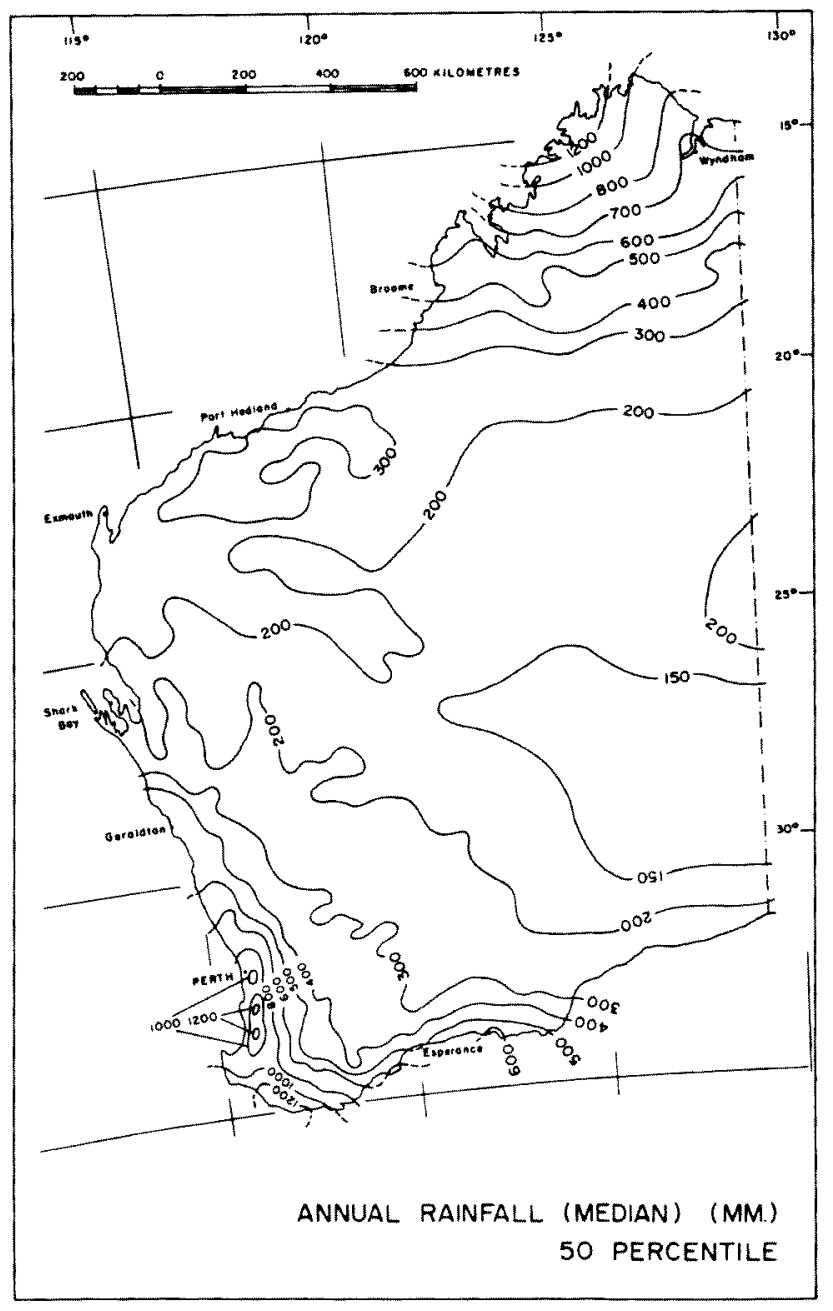

Figure 1 Median annual precipitation. 


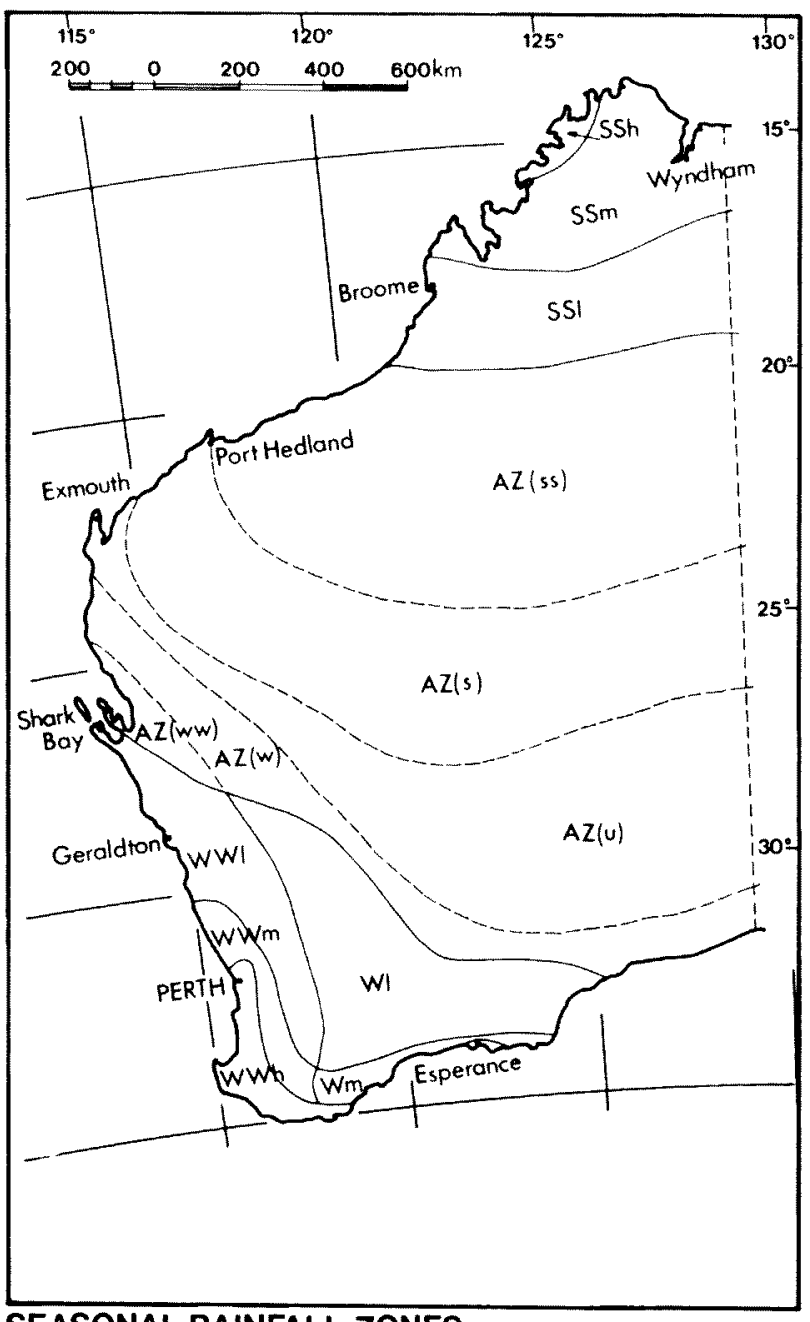

\section{SEASONAL RAINFALL ZONES}

CLASSIFICATION The classification is based on annual rainfall, seasonal

determined from the ratio (greater/lesser) of the median rainfalls:

November-April (Summer) and Moy-October (Winter).

\begin{tabular}{|c|c|c|c|c|c|c|c|}
\hline $\begin{array}{l}\text { SEASOMAL } \\
\text { MAXMMUM }\end{array}$ & $\begin{array}{l}\text { SEASONAL } \\
\text { AATHO }\end{array}$ & 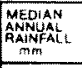 & 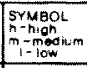 & $\begin{array}{l}\text { SEASONAL } \\
\text { MAXIMUMM }\end{array}$ & $\begin{array}{l}\text { SEASONAL } \\
\text { RAIOO }\end{array}$ & 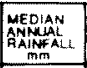 & 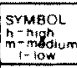 \\
\hline $\begin{array}{l}\text { Summer. } \\
\text { Oominantiss, } \\
\text { Summer is) } \\
\text { Untform iu) }\end{array}$ & $\left.\begin{array}{l}>3.0 \\
\begin{array}{c}5.0 \\
>1.3\end{array} \\
<1.3\end{array}\right\}$ & $\begin{array}{l}>1200 \\
6100-1200 \\
350-800 \\
>1200 \\
650-1200 \\
350+800 \\
>800 \\
500\end{array}$ & $\begin{array}{l}\text { ssm } \\
\text { ssm } \\
\text { ss! } \\
\text { sn } \\
\text { Sm } \\
\text { s } \\
\text { un }\end{array}$ & {$\left[\begin{array}{l}w_{\text {inter }}(w) \\
w_{\text {inter }}- \\
\text { Dominirent (ww) }\end{array}\right.$} & $\left.\begin{array}{l}\left.\begin{array}{c}<3.0 \\
>1.3\end{array}\right\} \\
>3.0\end{array}\right\}$ & \begin{tabular}{|l|}
$>800$ \\
$500-800$ \\
$220-800$ \\
$>800$ \\
$500-800$ \\
$250-500$ \\
$<350$
\end{tabular} & 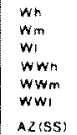 \\
\hline & & $\mid \begin{array}{l}500-800 \\
250-500\end{array}$ & $u_{u m}^{u m}$ & $(A y)$ & $\left.\begin{array}{r}53.0 \\
31.3 \\
<1.3\end{array}\right\}$ & $\begin{array}{l}<250 \\
<350 \\
<250 \\
<250 \\
\end{array}$ & $\begin{array}{l}A Z(w w) \\
A Z(S) \\
A Z(w) \\
A Z(w)\end{array}$ \\
\hline
\end{tabular}

Figure 2 Seasonal distribution of rainfall.

region. Cloud bands are most frequent in May and June and nearly all occur from April to September. They tend to persist between one and four days.

- Cold fronts and their accompanying midlatitude lows. Only a minority of cold frontal systems that sweep across Western Australia bring notable rainfall to the region. Strong systems that interact with a tropical moisture source however can produce significant rainfall. Interactions with northwest cloudbands in particular can generate widespread falls.

- Tropical depressions and tropical cyclones, the summer troughs and associated disturbances, and lows which can develop in the easterlies. More localised falls of rain can result from thunderstorm activity.

A distinct gradient in the seasonality of the precipitation occurs across the study area as is indicated by Figure 2. Rainfall generally occurs in May to July and January to March. June is the wettest month for much of the area.

The high variability of the rainfall regime both on a seasonal and annual basis is a characteristic feature of the study area. Annual rainfall totals are much less reliable in the Gascoyne region than in most other parts of Western Australia, apart from the arid interior. There is a significant probability that in some years some of the survey areas may receive less than $100 \mathrm{~mm}$ of precipitation (Figure 3). In the wettest 10 per cent of years annual rainfall exceeds $350 \mathrm{~mm}$ over most of the study area (Figure 4).

Variability can be expressed as: [ 90 th percentile 10 th percentile) / 50th percentile]. The southern part of the study area has the lowest variability value $(=1.0)$, indicating lower levels of variability.

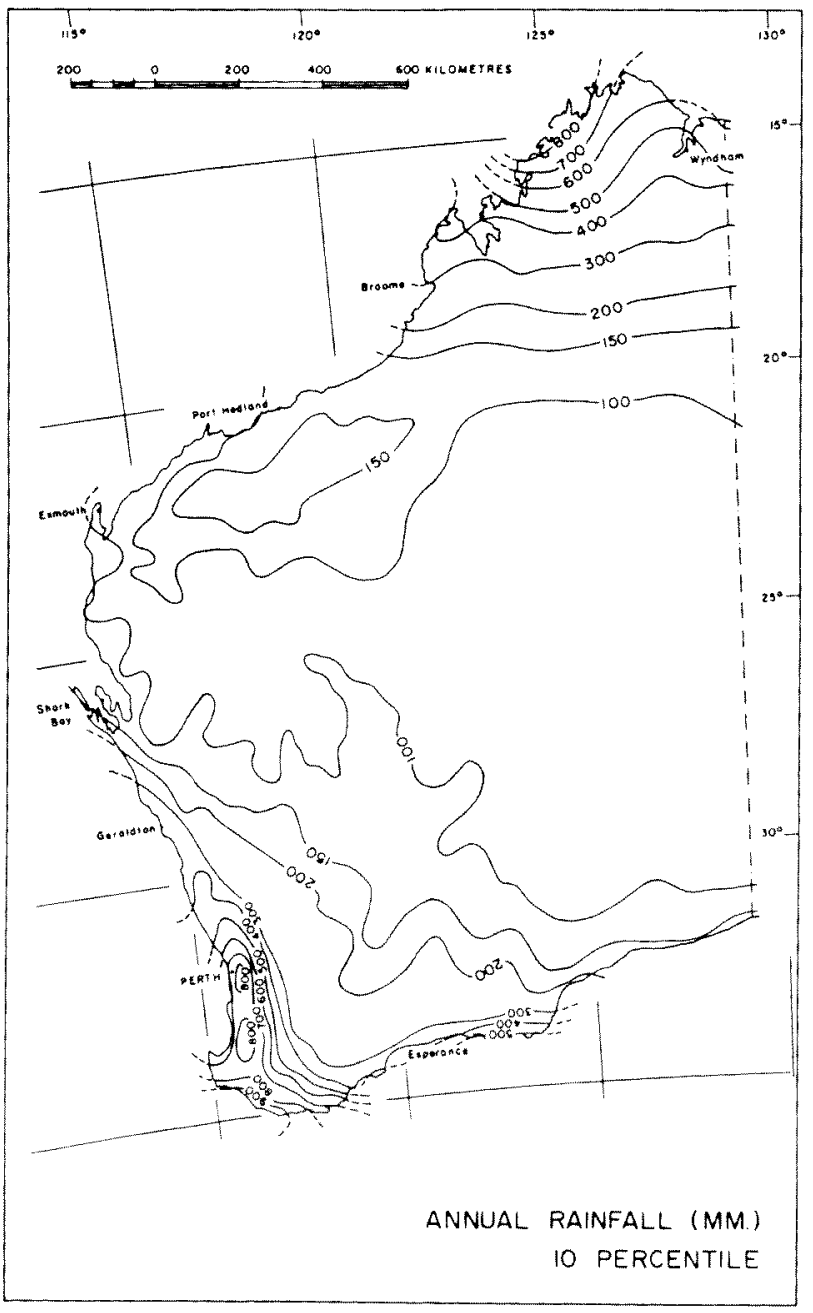

Figure 3 Annual rainfall-10th percentile. 


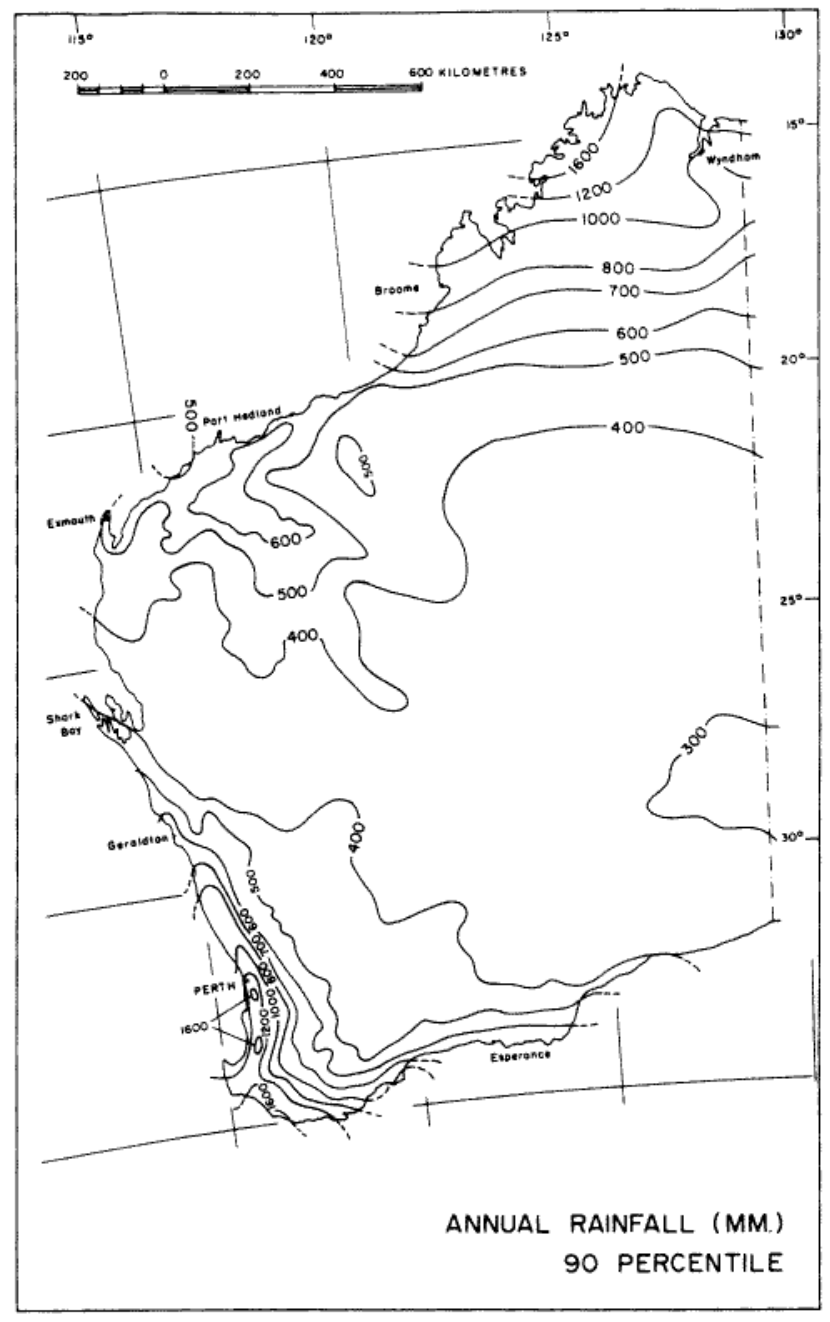

Figure 4 Annual rainfall - 90th percentile.

Values approach 1.5 over the northern part of the area, which indicates high variability.

A strongly negative mean annual water balance characterises the study area; the annual potential evaporation is significantly higher than mean annual rainfall. An overview of the mean annual evaporation is given in Figure 5. Evaporation in the Gascoyne typically reaches a peak in January when rates at Carnarvon average $10 \mathrm{~mm}$ per day. Winter rates are lowest, dropping to about $2 \mathrm{~mm}$ per day in the extreme south.

\section{The Temperature Regime}

The isotherms for selected parts of the year and specific temperature indices are given in Figures 69. Summer temperatures in the region are high and can be extreme. The highest temperature ever recorded in the region is $48.8^{\circ} \mathrm{C}$ at Gascoyne Junction (6 February 1991). The highest temperature recorded at Carnarvon is $47.7^{\circ} \mathrm{C}$ (23 January 1953). The average number of days per month when the maximum temperature exceeds $40^{\circ} \mathrm{C}$ in January ranges from about two at Carnarvon to a maximum of 19 days at Gascoyne Junction.
High temperatures can persist for extended periods. Gascoyne Junction experienced 51 consecutive days with temperatures above $40^{\circ} \mathrm{C}(5$ January to 24 February 1991) - including six consecutive days above $45^{\circ} \mathrm{C}(6-11$ February). This contrasts strongly with Carnarvon, where only once in 51 years, five or more consecutive days have had a maximum temperature over $40^{\circ} \mathrm{C}$.

Differences in the temperature regimes of the coastal and inland regions are directly related to the strong sea-breeze regime which the coastal region experiences. These temperature gradients are marked. For example, comparison over an 11 year period of January maximum temperatures at Carnarvon with those measured about $15 \mathrm{~km}$ inland at Brickhouse Woolshed revealed averages $5^{\circ} \mathrm{C}$ higher at the inland site. January averages continue to increase further inland, exceeding $40^{\circ} \mathrm{C}$ towards Gascoyne Junction. The ameliorating influence is also reflected in a comparison of the mean diurnal temperature range of the coastal and inland regions.

Average maxima decrease significantly during the autumn months and reach their lowest values in July. The temperature gradient is weakest along the

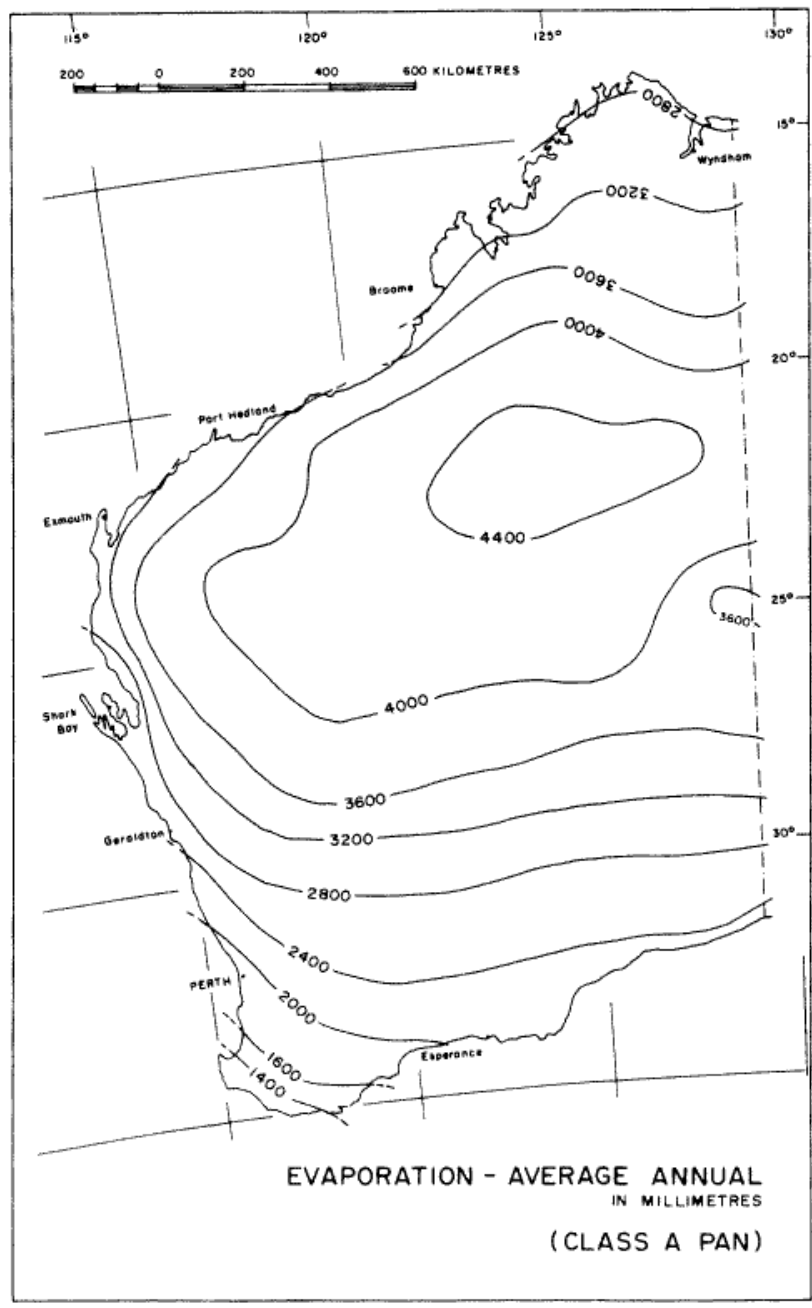

Figure 5 Average annual pan evaporation. 


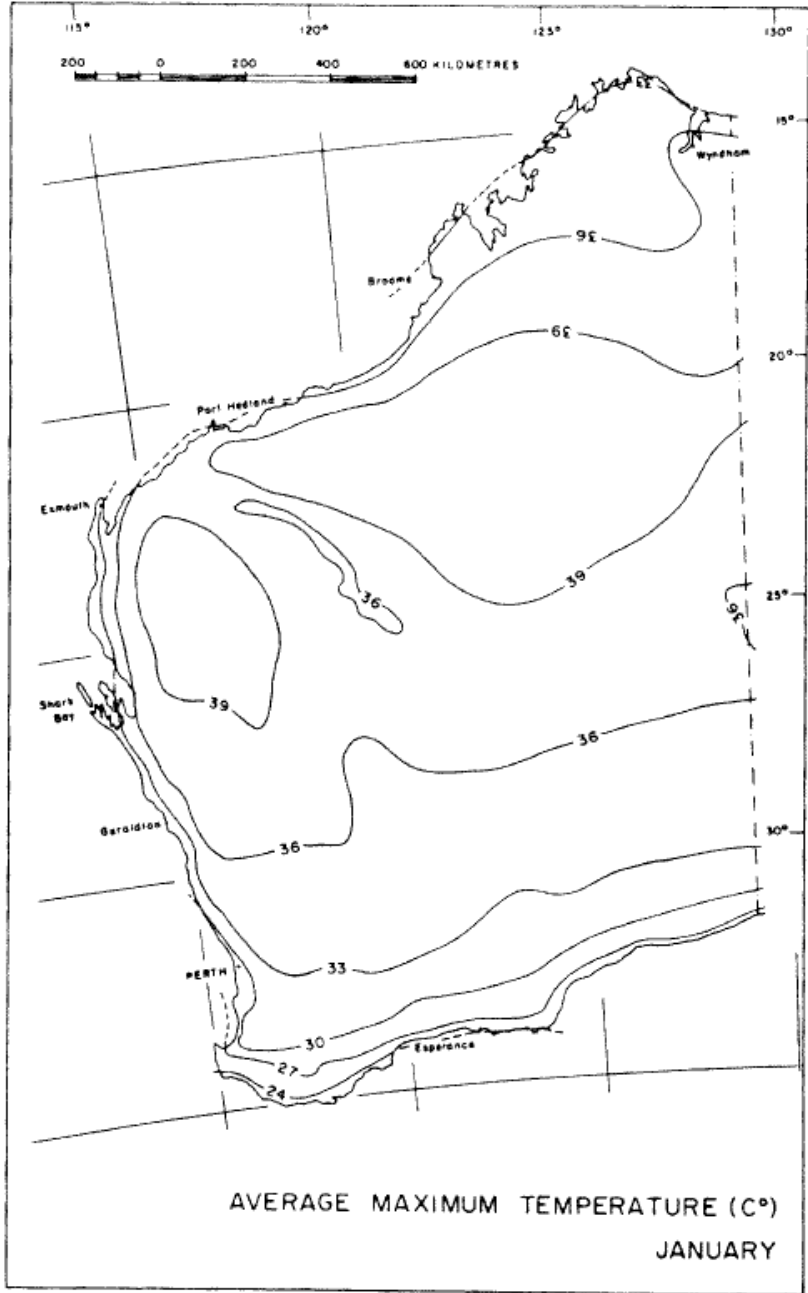

Figure 6 Average maximum January temperature.

coast at this time of the year. There is a general north - south gradient in the mean temperature of the coldest quarter. Coastal sites rarely experience ground temperatures below freezing. Brickhouse Woolshed, near Carnarvon, averages 2.7 days per year below $0^{\circ} \mathrm{C}$. Prolonged cold spells do not occur in the region.

Air temperature is measured in a Stevenson screen at a set height of about $1.2 \mathrm{~m}$. For much of the biota, temperatures (especially maximum/ minimum) measured directly at the soil surface or within the soil profile are likely to be of more importance than Stevenson screen temperatures. This is especially the case for seedlings and/or animals that live or refuge at or near the soil surface. Unfortunately, such temperature data are rare for the study area. Those that are available are summarised in Table 1.

\section{CLIMATE CHANGE AND VARIABILITY}

Considerations of evolutionary biogeography require an understanding of the paleoclimatic history of the region. A question which figures prominently is the date of onset of the present arid/ semi-arid climate of the region. Aridity, both present and past, is heavily imprinted on the biogeography and geomorphology of the region. But it was by no means persistent over the Late Cenozoic, and since its onset, significant climatic

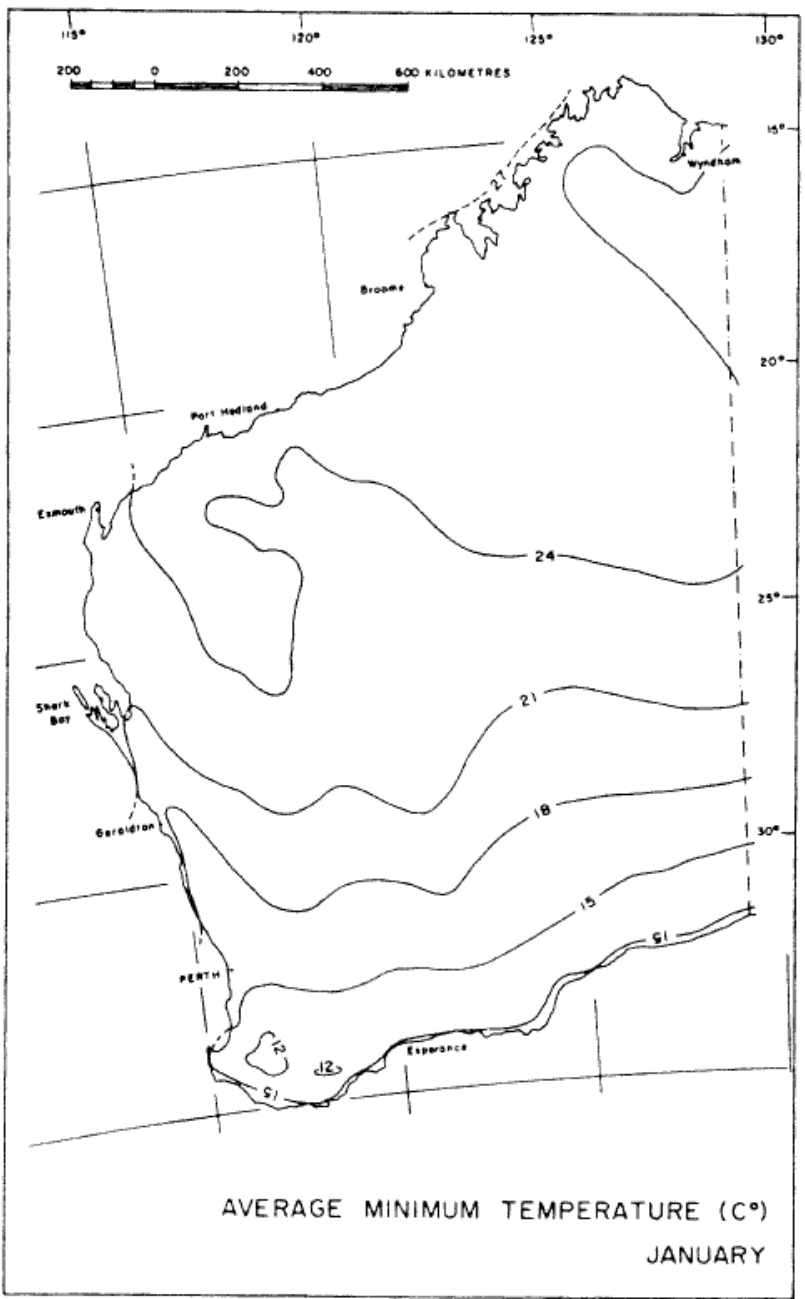

Figure 7 Average minimum January temperature.

Table 1 Monthly mean 9 am soil temperatures $\left({ }^{\circ} \mathrm{C}\right)$ at Brickhouse Woolshed (1966-1977).

\begin{tabular}{ccccccccccccc}
\hline Depth $(\mathrm{cm})$ & Jan & Feb & Mar & Apr & May & Jun & Jul & Aug & Sep & Oct & Nov & Dec \\
\hline 10 & 30 & 30 & 28 & 24 & 19 & 15 & 14 & 15 & 19 & 22 & 25 & 28 \\
20 & 31 & 32 & 30 & 26 & 22 & 17 & 16 & 17 & 21 & 24 & 27 & 30 \\
50 & 33 & 33 & 32 & 29 & 25 & 20 & 19 & 20 & 23 & 26 & 28 & 32 \\
100 & 32 & 32 & 32 & 30 & 27 & 23 & 21 & 21 & 23 & 25 & 27 & 30 \\
\hline
\end{tabular}




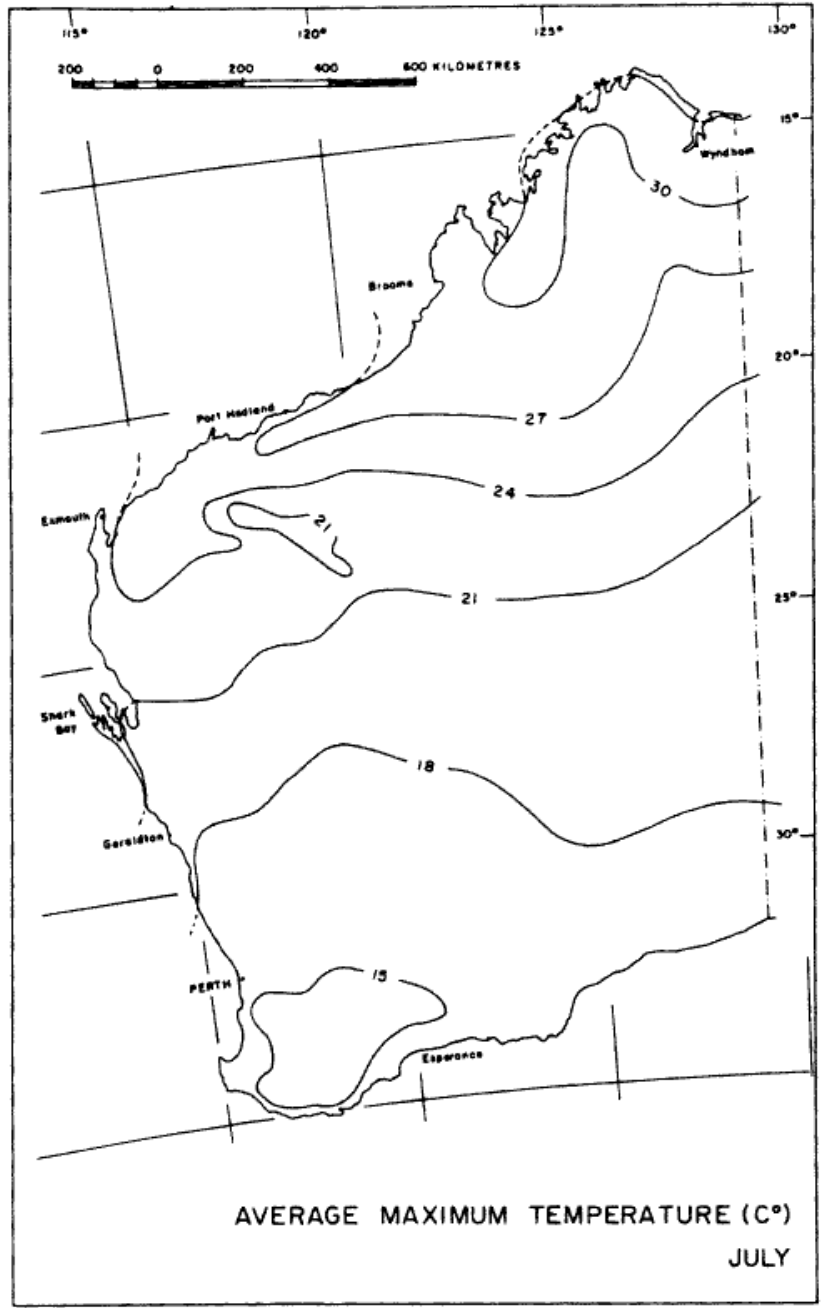

Figure 8 Average maximum July temperature.

changes are likely to have occurred in the region. These climate states in general will have been related to the global glacial-interglacial stages which have characterised global climates over Quaternary time-scales. When dealing with shorter (historical) time-scales it is often difficult to distinguish between climate variability and climate change. The time series of climate data necessary to allow a strict statistical separation between the two are seldom available. But regardless of whether historical data are a reflection of variability or change, such data need to be utilised to provide a more complete context in which to evaluate the present climate of a region.

\section{Late Cenozoic Time-scales}

The absence of a long-term climatic history specific to the region makes it impossible to provide a convincing framework into which likely evolutionary biogeographic events can be placed. An attempt is made to provide at least some of the paleoclimatic background by highlighting continental-scale reconstructions and placing these inferences into the context of the study area.
Paleoclimatic reconstruction centres on the reconstruction of temperature and precipitation/ hydrology. A consideration of the paleohydrology is of special significance. Any attempt to provide a theoretical/speculative outline of paleohydrological events is made difficult by the complex dynamic climatology of the region. As outlined in previous sections, the precipitation of the Carnarvon Basin is controlled by the westerlies of the south of the continent and the monsoon regime of the north. The difficulty is compounded by the importance of the northwest Australian cloud bands and their interaction with the frontal systems embedded in the westerlies. The combination of these mechanisms makes it difficult to provide 'speculative' outlines of possible paleoclimatic/ paleohydrological events. Nevertheless, an outline of aspects of the Late Cenozoic climatic history of the region has been attempted (Wyrwoll, 1993), and a partial summary of this discussion is given here, together with the details of more recent findings.

The basic question of the age of aridity remains largely unresolved. It is generally accepted that climatic conditions in Australia during much of the

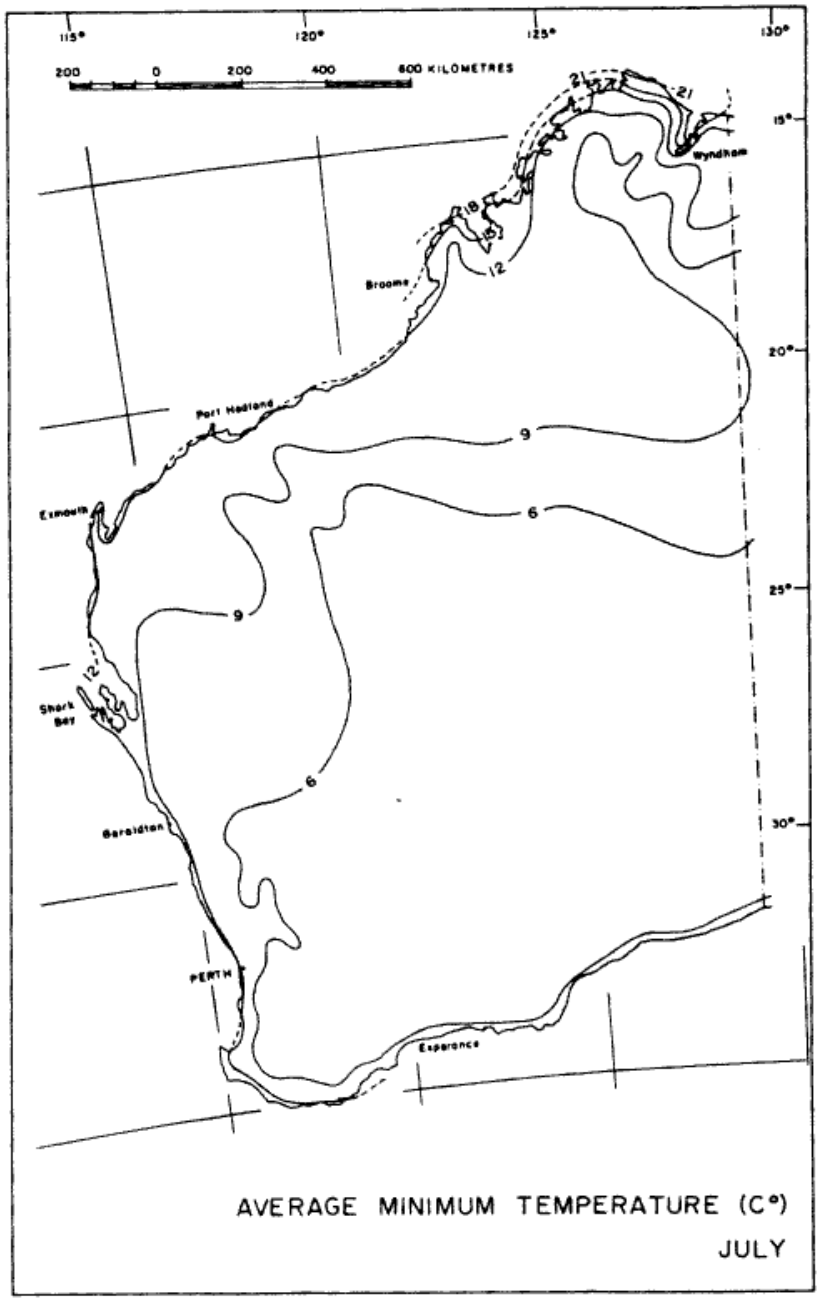

Figure 9 Average minimum July temperature. 
Tertiary were wetter than present (Kemp, 1978). The presence of araucariacian cones in the Eocene Merlinleigh Sandstone of the Carnarvon Basin indicates climatic conditions considerably wetter than those of today. The existence of wetter conditions during the Tertiary is linked with the evidence for deep weathering, which is pervasive throughout much of the Carnarvon Basin (van de Graaf, 1983; Hocking et al., 1987). Both ferricretes and silcretes, with their associated weathering profiles, are found in virtually all pre-Miocene outcrop areas, and also over some Miocene and younger (?) formations.

There is considerable uncertainty as to the timing of these deep weathering events. The appeal is often to general reviews such as Kemp (1978), to suggest the necessary climatic conditions for deep weathering came to an end with the onset of drier conditions which arose supposedly during the midMiocene. However, there is also the suggestion of post-Miocene 'laterisation' (Hocking et al., 1987), which may be viewed as evidence of a weathering regime requiring climatic conditions wetter than those which prevail today. Of some relevance to this discussion are recent findings from the Lake Lefroy region of the Yilgarn Craton, which indicate that intense weathering with associated silicification must have occurred in the region during the late Miocene ( $\mathrm{H}$. Zheng, pers. comm.). When combined, the evidence that is presently available, which comes from the Yilgarn Craton and the Perth and Carnarvon Basins, points to deep weathering events having taken place during the Oligocene and/to Late Miocene (Hocking et al., op. cit.; Zheng op. cit.; Schmidt and Embleton 1976).

There are now suggestions that the onset of full aridity may be more recent than previously thought. The work of Zheng et al. (1997) has demonstrated that in the Lake Lefroy region of the central Yilgarn, the onset of full arid conditions commenced within the Bruhnes Polarity Chron, probably within the last $500 \mathrm{Ka}$. Such a late onset of aridity does not tie in with the general conclusions derived from palynological work. But there are now three studies which suggest that the onset of full arid conditions throughout Australia may have been a Pleistocene event (Zheng et al., 1997; An et al., 1986; Chen and Barton, 1991). Given this timing, the question arises whether this shift to full arid conditions in Australia is somehow related to global changes in global ice-volumes and the changes in the dominant Milankovitch frequencies which occurred at about the Bruhnes/Matuyama geomagnetic boundary. Therefore, the suggestion that full arid conditions are a relatively recent event, now has to be seen as a likelihood (also see Williams, 1994).

Once the glacial-interglacial periodicities of the Bruhnes were established, the climate regime of this part of northern Australia may have approximated that of the Late Quaternary. The record of Quaternary climate events specific to the area is sparse. The only firmly dated event is the Last Glacial Maximum thermoluminescence age of the terrestrial dunes of the northernmost part of the Cape Range Peninsula (Wyrwoll, 1993) - which attest to more arid conditions prevailing in the region at that time.

There is evidence from both the monsoon region of the northwest and the northern Perth Basin which allows a tentative identification of some Quaternary paleoclimatic events which may have affected the region. For northern Australia, the pollen record of a number of deep sea cores shows a major change of eucalypt forest to grassland during the last glacial period (Van der Kaars, 1991). The vegetation changes indicate significant decreases in precipitation over northern Australia at that time. It is claimed that the core record reveals expansions and contractions of the arid zone over the last $300 \mathrm{Ka}$. From the inferred ages it is suggested that these repetitions were not mirror images of the last glacial period. If the inferred dates are accepted the pollen record appears to indicate that the overall climate of northern Australia before circa $190 \mathrm{Ka}$ BP was persistently much wetter with a much larger proportion of eucalypt woodland in the vegetation. This claim is supported by some preliminary results from Lake Gregory which suggest a massive phase of lake expansion during the Middle Pleistocene. During the Last Interglacial the lake extent appears to have been greater than during the Holocene (Wyrwoll et al., 1996).

The available data make it evident that glacial stages were generally drier in northern regions and that the most extreme reductions in precipitation over northwestern Australia coincided with glacial maxima. This inference is further supported by the clear indications that at glacial maxima the mean surface temperature of the low latitude regions was reduced by as much as $5^{\circ} \mathrm{C}$ (Guilderson et al., 1994; Stute et al., 1995). Such a massive reduction in temperatures would have far reaching implications on the moisture content of the tropical atmosphere, tropical convection, the existence of the Pilbara Heat Low, and through these on the functioning of a monsoon regime over northern Australia. Associated with these changes would have been a significant reduction in the potential for tropical cyclone genesis (Gray, 1988; Hobgood and Cerveny, 1988). From these considerations alone, one would expect a significant reduction in summer precipitation over northwestern Australia. The direct evidence for widespread drier conditions at the Last Glacial Maximum is provided by a set of dunes in the northern part of the Cape Range region (Wyrwoll et al., 1993). But with this evidence goes 

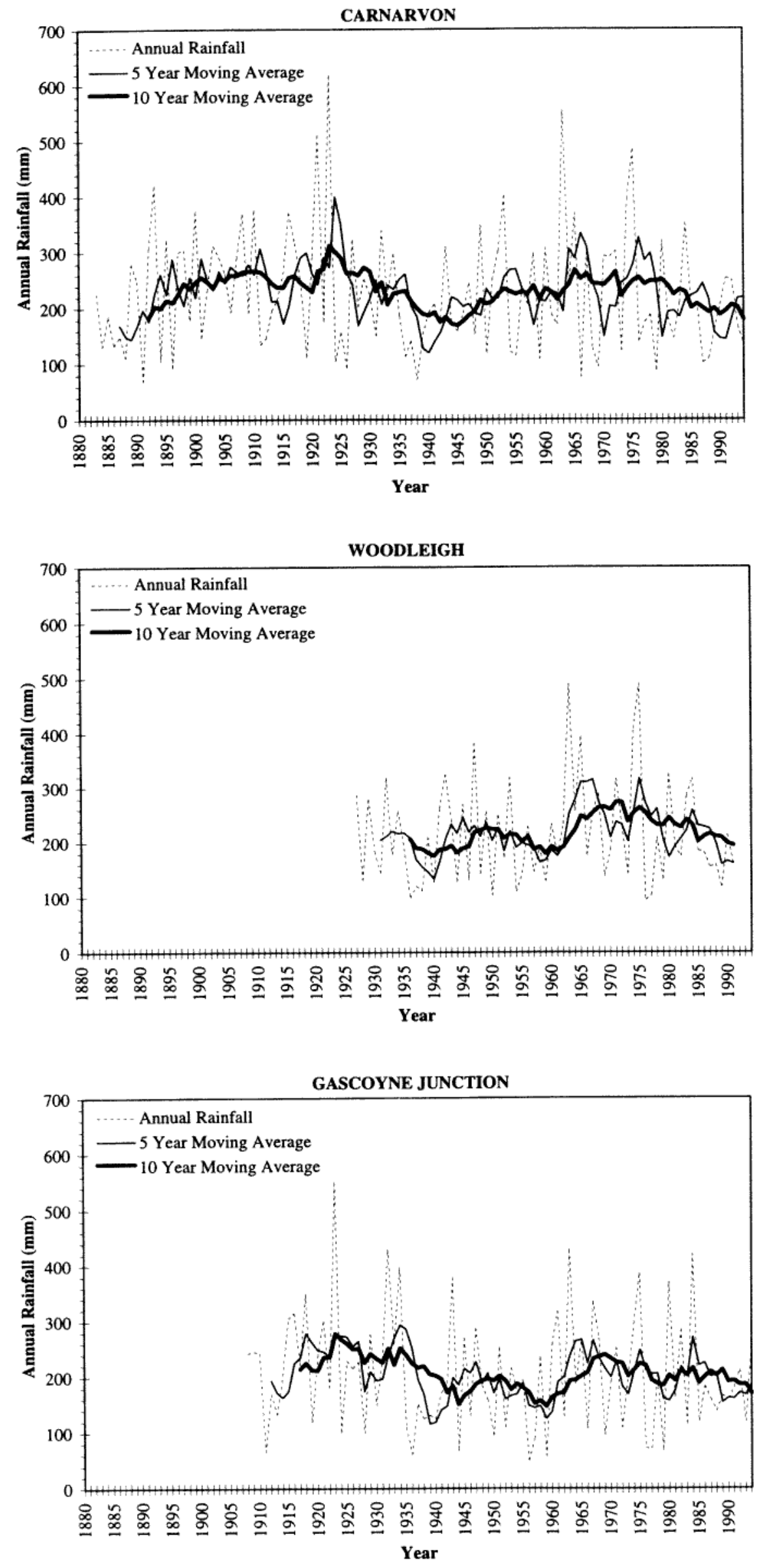

Figure 10 Historical rainfall record for selected stations. 
the suggestion that, at least as far as summer precipitation is concerned, most of the last 100000 years are likely to have seen conditions in much of the Carnarvon Basin drier than those of the present.

The other two synoptic precipitation sources which determine winter rainfall, the frontal systems embedded in the westerlies and the so called northwest Australian cloud bands, are likely to have been significantly different during glacial stages. At glacial maxima lower sea surface temperatures in tropical regions and a significantly drier atmosphere would have made it more difficult for the formation of these cloud bands. The field evidence suggests there were times during the Late Pleistocene during which the influence of frontal systems may have been more restricted to the south. The evidence comes from the northern Perth Basin and takes the form of thermoluminescence dates which point to periods of dune mobility at c. 15, 45, 71 and $114 \mathrm{Ka} \mathrm{BP}$ (Wyrwoll and Newsome, 1999).

CLIMAP-based attempts to model Last Glacial Maxima climatic conditions have not been particularly informative for Australia (e.g. Kutzbach et al., 1993), and for northern Australia are now largely redundant because of revised tropical surface temperatures. But despite this model, output has been consistent with empirical data in suggesting that during late glacial stages areas associated with a westerly (winter) rainfall regime saw a significant reduction in mean annual rainfall (e.g. Harrison and Dodson, 1993). The STH is a dynamic feature associated with low latitude energy and momentum transfer and results from deep subsistence. During glacial stages, when mean surface temperatures over southern Australia were decreased by as much as $5^{\circ} \mathrm{C}$ (Miller and McGee, 1997), the dynamic high pressure cells would have been enhanced by the temperature structure of the lower troposphere. Such conditions are likely to have led to the development of strong 'blocking' highs and with them an outward extension of the arid zone.

The climates of the region over Holocene timescales remains largely unknown. Data from the Great Sandy Desert (Wyrwoll et al., 1986, 1992) suggest that in that region of northern Australia monsoon activity was subdued until well into the Holocene. More recent findings from the Fitzroy Trough (Wyrwoll et al., 1996) indicate that the monsoon was active in that area by $\mathrm{c} .12 \mathrm{Ka} \mathrm{BP}$. But for the southern Kimberley and northern Great Sandy Desert, the record of monsoon activity after c. $12 \mathrm{Ka} \mathrm{BP}$ and before $\mathrm{c} .7 \mathrm{Ka} \mathrm{BP}$ remains unclear. The Holocene pollen record from the southwest shows that lake levels and general hydrological conditions did not show any marked changes during the Holocene (Newsome and Pickett, 1993). From the evidence now available it is reasonable to conclude that, at present, there is no evidence which points to significant climate changes in the Carnarvon Basin during the Holocene.

Using the Late Quatemary climatic record as a guide to the general climate states of the Bruhnes Chron, suggests that during glacial stages the Carnarvon Basin region experienced conditions significantly drier than those of today, with aridity becoming most marked at glacial maxima. During interglacials the region would have experienced climatic conditions similar to those which prevail today - although with some interglacial stages possibly significantly wetter than the Holocene as a result of increased summer precipitation. Whatever the correct details of the Quaternary climatic history of the region may eventually prove to be, it is clear from the available information that Quaternary climate changes would have exerted a profound influence on the biogeography of the region.

\section{Climate Variability over Historical Time Scales}

The climate of the region has a high natural variability and droughts are legendary elements of life in the Gascoyne. The Elder Expedition (18911892) noted: "The Murchison and Upper Gascoyne suffered terribly from the prolonged and serious drought. Not a vestige of food or vegetation was to be seen, and the losses of stock were enormous". The historical record of rainfall covers some 100 years and from this some indication of variability in regional climate can be obtained. The length of the historical record is however, unlikely to be sufficient to encompass the range of variability inherent in the present climatic regime of the region.

Precipitation variations appear to have no real trend over the time period for which the records are available. Pittock (1988) claims that much of the study area saw an increase in winter precipitation of $0.07 \%$ per decade for the period 1913-1986 (not statistically significant). This is in a region where much of the mean annual rainfall may result from one or two synoptic-scale events. The records show that the annual rainfall received is quite variable and there is often a persistence of low rainfall years. Figure 10 illustrates the historical rainfall record for representative locations in the study area. When referring to these records the patchy distribution of rainfall over the study area has to be borne in mind. For instance, from 1935 to 1938 Binthalya (Kennedy Range survey site) received only $387.5 \mathrm{~mm}(42$ percent of its average rainfall) while at Eudamullah, some $85 \mathrm{~km}$ away, $670.2 \mathrm{~mm}$ was recorded $(82$ percent of its average) for the same period.

Foley (1957) reviewed historical droughts from the earliest years of records to 1955. This has been combined with other information (Bureau of Meteorology, in prep.) to show that the most severe drought periods have been those of 1891-1892, 1911-1914, 1935-1941, 1943-1945 and 1976-1979. The 1935-1941 drought was undoubtably the worst 
on record, when successive years had below average rainfall. Throughout the entire region the total rainfall for 1935 to 1940 was just 50 to 70 per cent of the long term average.

Using a soil water balance model (WATBAL) it has been shown (I. Foster, personal communication) that amongst the worst seasons this century for winter pasture growth in the wider region have been 1922, 1935, 1937, 1955, 1976, 1982, 1988, and 1991. In each of these years there were no more than 20 days of continuous growth as defined by the model. These extreme hydrological variations, coupled with land-use practices have resulted in the claim that this area is susceptible to desertification (Biswas et al., 1980; Williams et al., 1980). This needs to be evaluated in the light of the present understanding of the overall issue of desertification (e.g. Le Houerou, 1996; Mainguet, 1991).

For much of the Australian continent ENSO events exert a strong influence on rainfall patterns but for Western Australia such a relationship is less obvious. However recent studies by Nicholls (1989), Drosdowsky (1993) and Smith (1994) have indicated that the Australian winter rainfall is related to sea surface temperatures (SST) patterns in the Indian Ocean. It appears that there is a clear relationship between a SST anomaly pattern described as the Indian Ocean dipole (the difference in the SSTs between the Indonesian region and the central Indian Ocean) and winter rainfall in the Australian region.

The links between the SST anomalies, changes in the atmospheric circulation and winter rainfall remain unclear. The relationships must incorporate atmospheric circulation variations, establishing a link between Indian Ocean sea surface temperatures and the occurrence and frequency of northwest cloud bands. It is of note, therefore, that Wright (1996) found that the percentage of April to October rainfall produced by these cloud bands increased from about 50 per cent in the south of the study area to over 80 per cent in the north of the Gascoyne. Wright also found that there was an average of ten significant events, defined as falls greater than $10 \mathrm{~mm}$ at one or more sites within a representative observation network in northwestern Australia each year.

Precipitation in the region is related to the synoptic systems related to the winter rainfall regime of the south (frontal systems) and the summer regime of the north (monsoon). Only a minority of cold fronts that affect Western Australia extend as far north as the central part of the study area. The southernmost sample sites are more frequently affected by winter frontal systems. This is reflected in the higher winter rainfall which these sites receive. These sites may have seen a decrease in winter rainfall over the period 1913-1986. This decrease may have amounted to as much as $4.8 \%$ per decade (Pittock, 1988) and appears to be related to increases in mean sea level pressure (Allan and Haylock, 1993). The overall significance to the study area is not clear. Heavy rainfall events result from the interaction between frontal systems and tropical moisture sources. Occasions when a two-day rainfall total exceeded $20 \mathrm{~mm}$ were identified in the 11 year period 1985 to 1995 . Of 27 events at Carnarvon, 13 were associated with cold fronts.

There are indications that annual temperature maxima, and to a lesser extent minima, have increased from 1951 to 1992 (Torok and Nicholls, 1996). In particular annual maxima have exhibited a distinct rise since the early 1970s. Data sets are available for the Carnarvon Post Office (1885-1944) and the Carnarvon Meteorological Office (19451995). The Carnarvon Meteorological Office shows a long term average of $27.0^{\circ} \mathrm{C}$, the 1945 to 1970 average of $26.6^{\circ} \mathrm{C}$ is well below the 1971 to 1995 average of $27.4^{\circ} \mathrm{C}$. In particular, summer-time maxima have risen: the number of maxima above $35^{\circ} \mathrm{C}$ has increased from $24.9(1951-1974)$ to 28.9 (1975-1995).

\section{Future Climates}

Given our present understanding of global climate processes there now exists good reason to expect changes in global and regional climates under enhanced Greenhouse conditions. The predictions that are available are at the global/ continental scale and it remains difficult to translate these to a regional climate. It needs to be stressed that climate change will manifest itself not only in the changes in 'mean states' but will be expressed through the magnitude and frequency of events. Given the climatic characteristics of the study area, in which probability of occurrence of precipitation events is so important, magnitude/frequency considerations become especially significant. This is an issue that cannot be resolved, but it is one which needs to be kept in mind.

\section{Conclusions}

The study area provides a range of climate settings which, in association with a mosaic of geomorphological and soil environments, provide the physical context for the biogeographical work. The association between the physical context and the biology is indicated by an 'interaction matrix'. In detail, any explanation of the biogeographical patterning of a landscape also needs to be placed into a historical context, and much of this is still incomplete. Consequently, at this stage only a very incomplete account of the biogeographical evolution is available.

\section{ACKNOWLEDGEMENTS}

We thank the referees for their helpful comments, 
criticisms and the general trouble they took in refereeing a paper which was written in difficult circumstances. Funding was provided by the Commonwealth through the National Reserves System Co-operative Program of the Australian Nature Conservation Agency, and by the Western Australian Department of Conservation and Land Management.

\section{REFERENCES}

Allan, R.J. and Haylock, M.R. (1993). Circulation features associated with the winter rainfall decrease in southwestern Australia. Journal of Climate 6: $1356-$ 1367.

An, Z.S., Bowler, J.M., Opdyke N.D., Macumber, P.G. and Firman, J.B. (1986). Palaeomagnetic stratigraphy of Lake Bungunnia: Plio-Pleistocene precursor of aridity in the Murray Basin, southeastern Australia. Palaeogeography, Palaeoclimatology, Palaeoecology 54: 219-239.

Biswas, M.R. and Biswas, A.K. (eds) (1980). Desertification: Associated Case Studies Prepared for the United Nations Conference on Desertification. Permagon Press, New York.

Burbidge, A.H., McKenzie, N.L. and Harvey, M.S. (2000). A biogeographic survey of the southern Carnarvon Basin, Western Australia: background and methods. Records of the Western Australian Museum Supplement No. 61: 1-12.

Busby, J.R. (1991). BIOCLIM - A Bioclimatic Analysis and Prediction System. In C.R. Margules and M.P. Austin (eds), Nature Conservation: Cost Effective Biological Surveys and Data Analysis: 64 68. CSIRO, Canberra.

Chen, X.Y. and Barton, C.E. (1991). Onset of aridity and dune building in central Australia: Sedimentological and magnetostratigraphic evidence from Lake Amadeus. Palaeogeography, Palaeoclimatology, Palaeoecology 84: 55-73.

Drosdowsky, W. (1993). A method of forecasting winter rainfall over southern and eastern Australia. Australian Meteorological Magazine 42: 1-6.

Foley, J.C. (1957). Droughts in Australia. Bulletin No, 43. Bureau of Meteorology, Australia.

Gray, W.M. (1988). Environmental influences on tropical cyclones. Australian Meteorological Magazine 36: $127-$ 139.

Guilderson, T.P., Fairbanks, R.G. and Ruberstone, J.L. (1994). Tropical temperature variations since 20,000 years ago: modulating interhemispheric climate change. Science 263: 663-665.

Harrison, S.P. and Dodson, J. (1993). Climate of Australia and New Zealand since 18,000 yr B.P. In H.E. Wright Jr., J.E. Kutzbach, T. Webb III, W.F. Ruddiman, F.A. Street-Perrott, and P.J. Bartlein (eds), Global Climates Since the Last Glacial Maximum: 265-293. University of Minnesota Press, Minneapolis.

Hobgood, J.S and Cerveny, R.S. (1988). Ice-age hurricanes and tropical storms. Nature 333: 243-245.

Hocking, R.M., Moors, H.T. and van de Graaff, W.J.E. (1987). Geology of the Carnarvon Basin. Bulletin 133. Geological Survey of Western Australia, Perth.
Kemp, E.M. (1978). Tertiary climatic evolution and vegetation history in the southeast Indian Ocean region. Palaeogeography, Palaeoclimatology, Palaeoecology 24: 169-208.

Kutzbach, J.E., Guetter, P.J., Behling, P.J. and Selin, R. (1993). Simulated climatic changes: results of the COHMAP climate model experiments. In H.E. Wright Jr., J.E. Kutzbach, T. Webb III, W.F. Ruddiman, F.A. Street-Perrott and P.J. Bartlein (eds), Global Climates Since the Last Glacial Maximum: 24-93. University of Minnesota Press, Minneapolis.

Le Houerou, H.N. (1996). Climate change, drought and desertification. Journal of Arid Environments 34: 133185.

Mainguet, M. (1991). Desertification: Natural Background and Human Management. Springer-Verlag, Berlin.

Miller, G. H., McGee J.W. and Jull, A.J.T. (1997). Lowlatitude glacial cooling in the Southern Hemisphere from amino-acid racemization in emu eggshells. Nature 385: 241-244.

Newsome, J.C. and Pickett, E.J. (1993). Palynology and palaeoclimatic interpretations of two Holocene sequences from southwestern Australia. Palaeogeography, Palaeoclimatology, Palaeoecology 101: 245-261.

Nicholls, N. (1989). Sea surface temperatures and Australian winter rainfall. Journal of Climate 2: 965973.

Nix, H.A. (1986). A biogeographic analysis of Australian Elapsid Snakes. In R. Longmore (ed.), Atlas of Elapid Snakes of Australia: 4-15. Australian Flora and Fauna Series Number 7. Australian Government Publishing Service, Canberra.

Pittock, A.B. (1988) Actual and anticipated changes in Australia's climate. In G.I. Pearman (ed.), Greenhouse Planning for Climate Change: 35-51. Brill, Leiden

Schmidt, P.W. and Embleton, B.J.J. (1976). Palaeomagnetic results from sediments of the Perth Basin, Western Australia and their bearing on the timing of regional laterisation. Palaeogeography, Palaeoclimatology, Palaeoecology 19: 257-273.

Smith, I. (1994). The potential for an improvement in the predictability of Australian seasonal rainfall using sea surface temperatures. International Journal of Climatology 14: 611-623.

Stute, M., Schlosser, P., Clark, J.F. and Broecker, W.S. (1994). Paleotemperatures in the southwestern United States derived from noble gases in ground water. Science 269: 46-50.

Sturman, A.P. and Tapper, N.J. (1996). The Weather and Climate of Australia and New Zealand. Oxford University Press, Melbourne.

Tapp, R.G. and Barrell, S.L. (1984). The northwest Australian cloud band: climatology, characteristics and factors associated with development. Journal of Climatology 4: 411-424.

Torok, S.J. and Nicholls, N. (1996). An historical annual temperature dataset for Australia. Australian Meterological Magazine 45(4): 251-260.

Van de Graaf, W.J.E. (1983). Silcrete in Western Australia: geomorphological settings, textures, structures, and their genetic implications. In R.C.L. Wilson (ed.), 
Residual Deposits: Surface Related Weathering Processes and Materials: 159-166. Special Publication No 11. Geological Society, London.

Van der Kaars, W.A. (1991). Palynology of Eastern Indonesian marine piston-cores: A Late Quaternary vegetational and climatic record for Australasia. Palaeogeography, Palaeoclimatology, Palaeoecology 85: 239-302.

Wahla, G. and Wendelberger, J. (1980). Some new mathematical methods for variational objective analysis using splines and cross validation. Monthly Weather Review 108: 1122-1143.

Williams, M.A.J. (1994). Cenozoic climatic changes in deserts: a synthesis. In A.D. Abrahams and A.J. Parson (eds), Geomorphology of Desert Environments: 644-670. Chapman and Hall, London.

Williams, O.B., Suijdendorp, H. and D.G. Wilcox (1980). The Gascoyne Basin. In R. Biswas and A. Biswas (eds), Desertification: Associated Case Studies Prepared for the United Nations Conference on Desertification. Permagon Press, New York.

Wright, W.J. (1996). Tropical-extratropical cloudbands and Australian rainfall. 1. Climatology. International Journal of Climatology 17(8): 807-829.

Wyrwoll, K.-H. (1993). An outline of Quaternary palaeoclimatic events in the Exmouth Gulf - Cape Range region. Records of the Western Australian Museum Supplement No. 45: 39-50.
Wyrwoll, K.-H., Bowler, J.M. Lu, Y., Collins, L.B. and Zheng, H. (1996). The north-west Australian monsoon. 30th International Geological Congress, Abstract: 648 . Beijing, China.

Wyrwoll, K.-H., Hopwood, J. and McKenzie, N.L. (1992). The Holocene paleohydrology and climatic history of the northern Great Sandy Desert-Fitzroy Trough: with special reference to the history of the northwest Australian monsoon. Climatic Change 22: 47-65.

Wyrwoll, K.-H., McKenzie, N.L., Pederson, B.J. and Tapley, I.J. (1986). The Great Sandy Desert of northwestern Australia: The last 7000 years. Search 17: 208-211.

Wyrwoll, K.-H. and Newsome D. (2000). The paleoclimatic significance of luminescence dates of periods of Late Quaternary dune mobility in the northern Perth Basin, Western Australia. Palaeogeography, Palaeoclimatology, Palaeoecology (submitted).

Zheng, H., Wyrwoll, K.-H., Li, X.I. and Powell, C. (1997). The timing of the onset of Late Cenozoic aridity in southwestern Australia. Global and Planetary Change 18: $175-187$.

Manuscript received 5 August 1998; accepted 3 December 1999. 
APPENDIX 1: BIOCLIM SURFACES

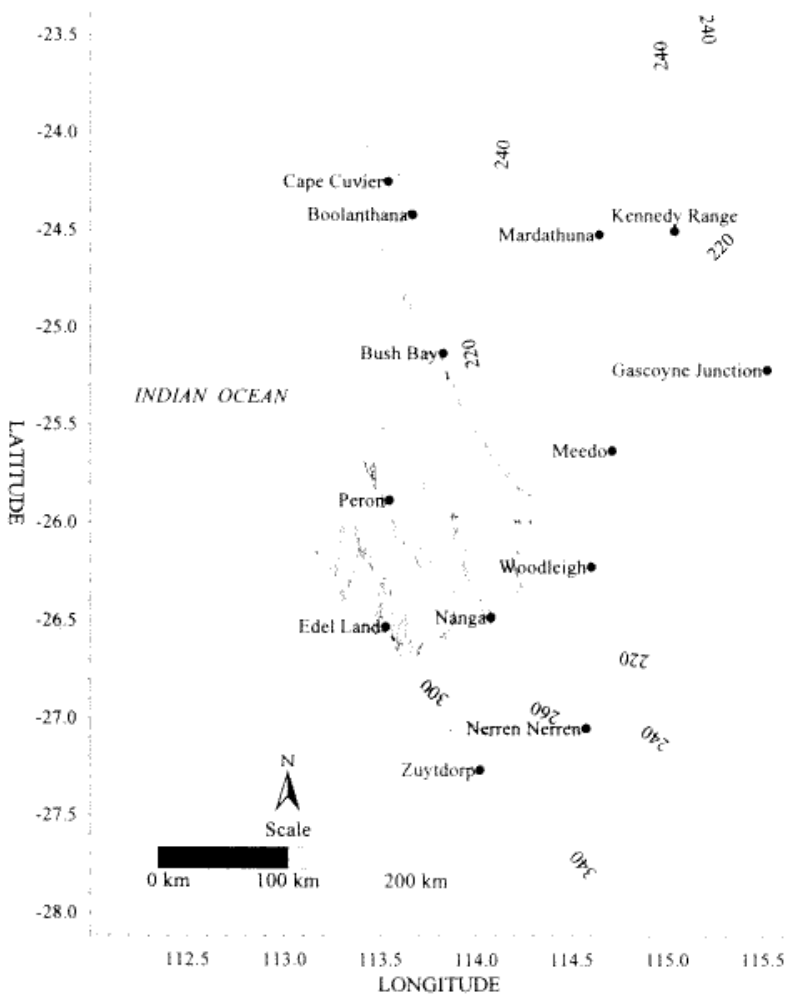

Figure A1 Mean annual precipitation.

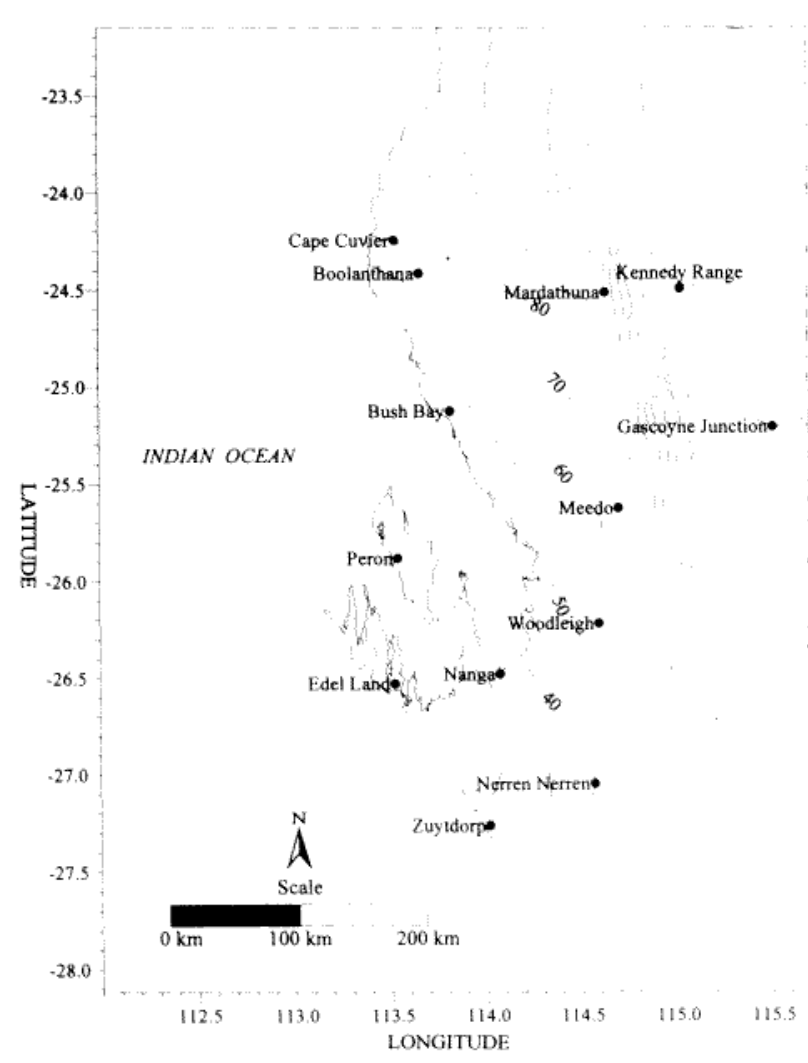

Figure A3 Mean precipitation of warmest quarter.

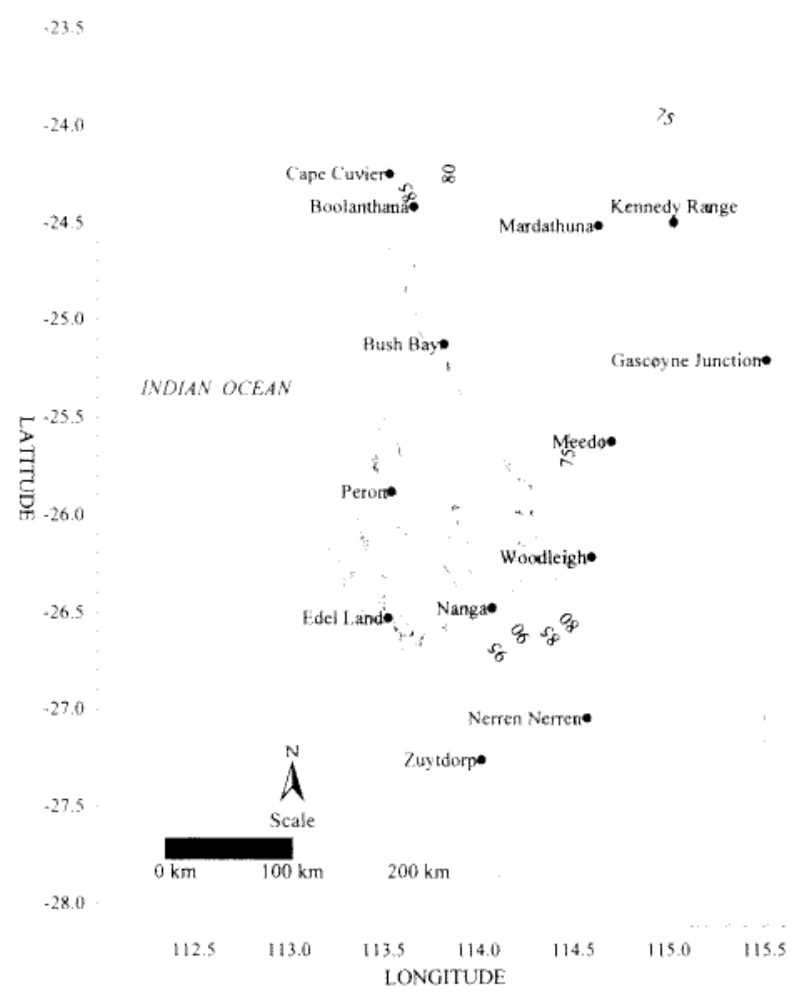

Figure A2 Precipitation seasonality.

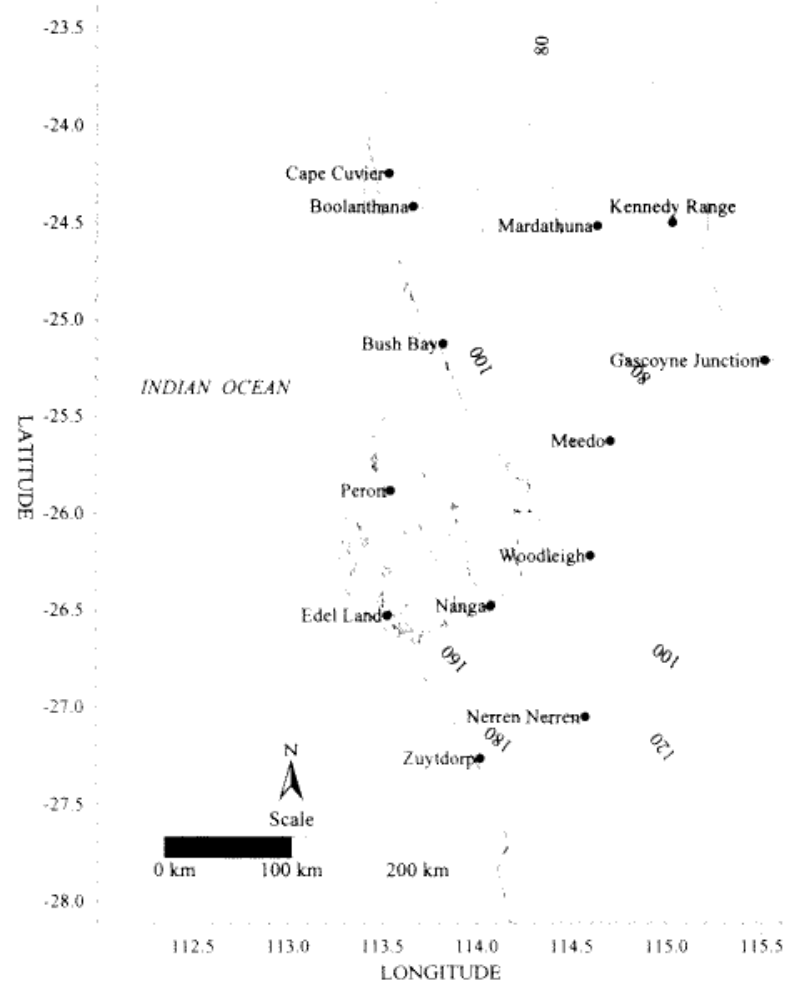

Figure A4 Mean precipitation of coldest quarter. 


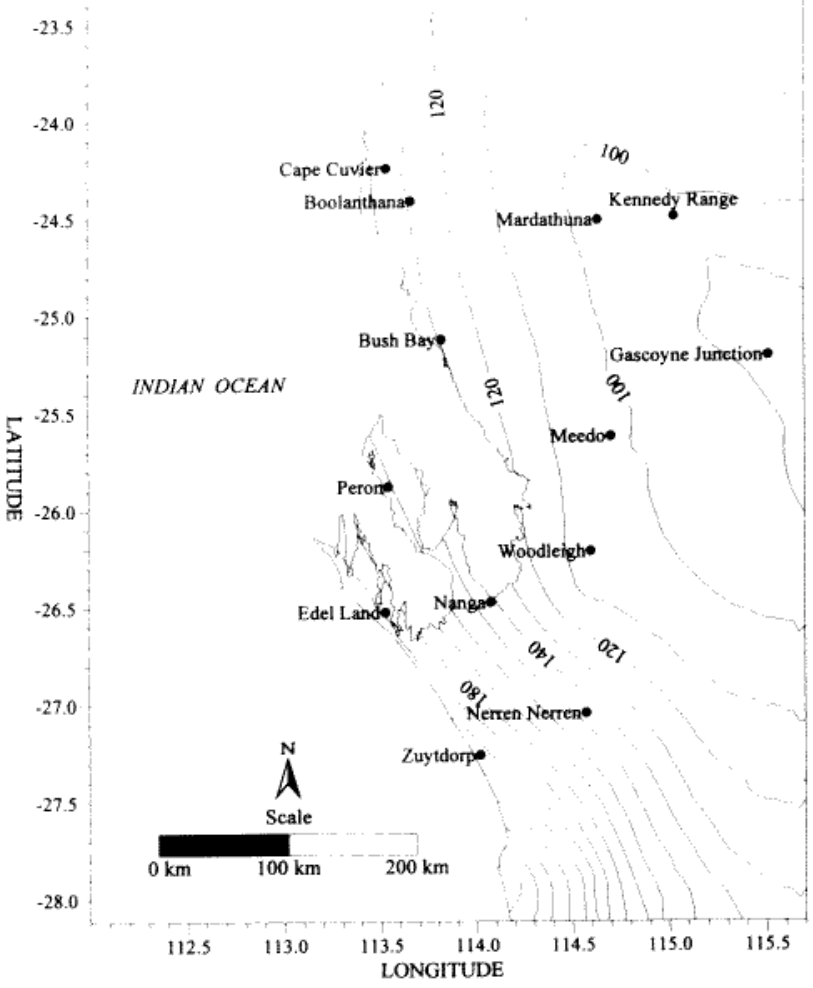

Figure A5 Mean precipitation of wettest quarter.

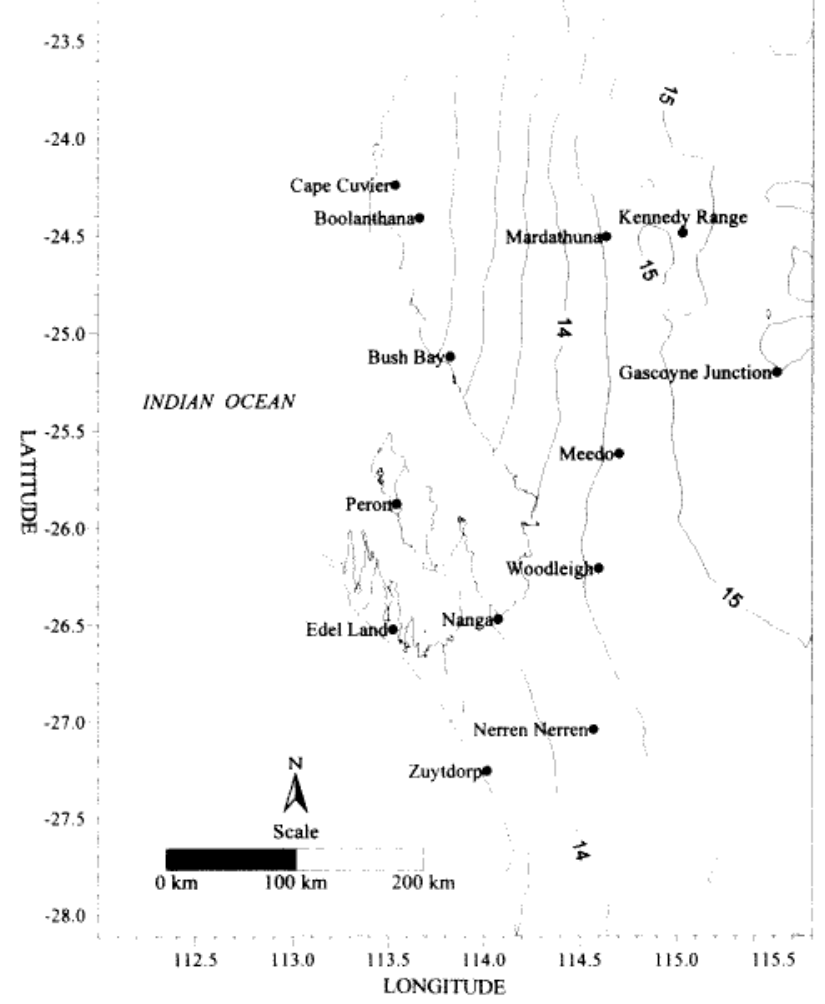

Figure A7 Annual temperature range.

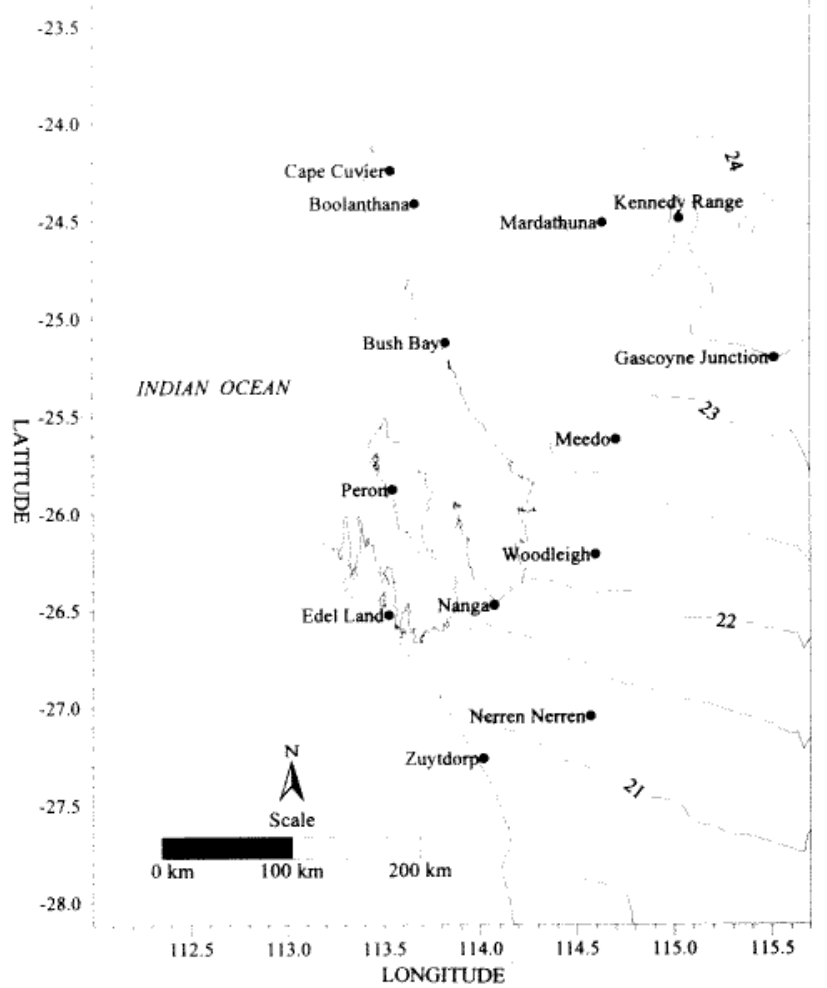

Figure A6 Annual mean temperature.

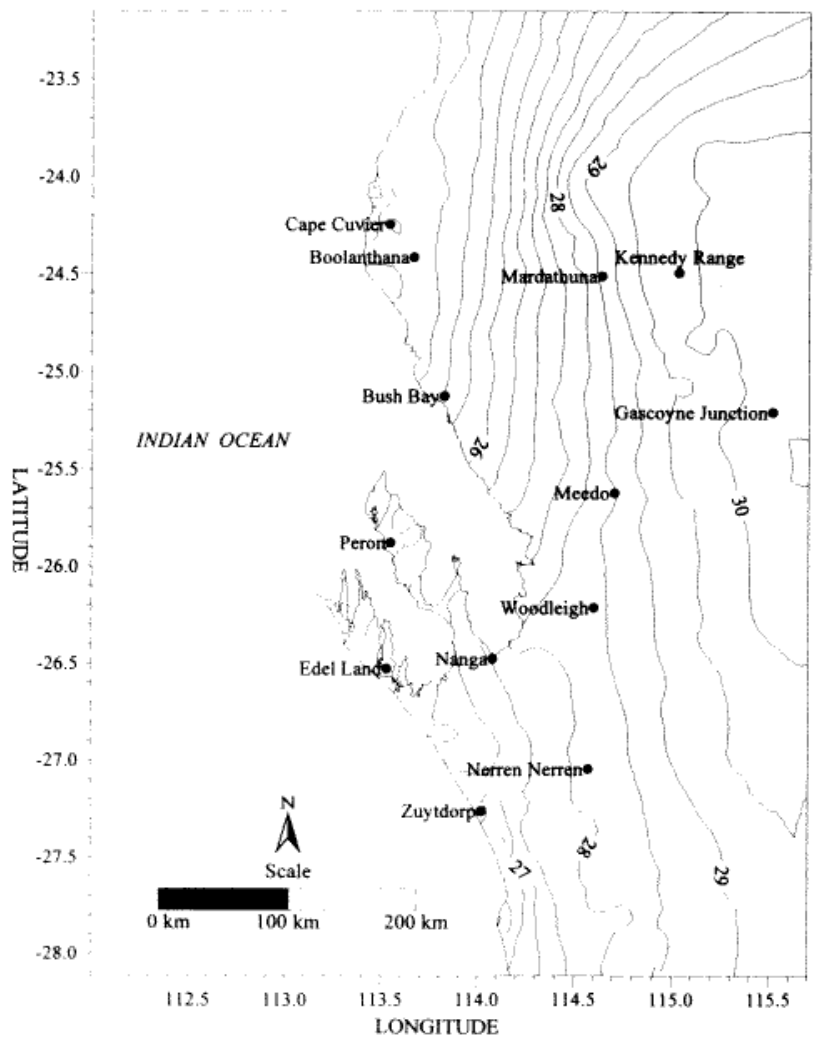

Figure A8 Mean diurnal temperature range. 


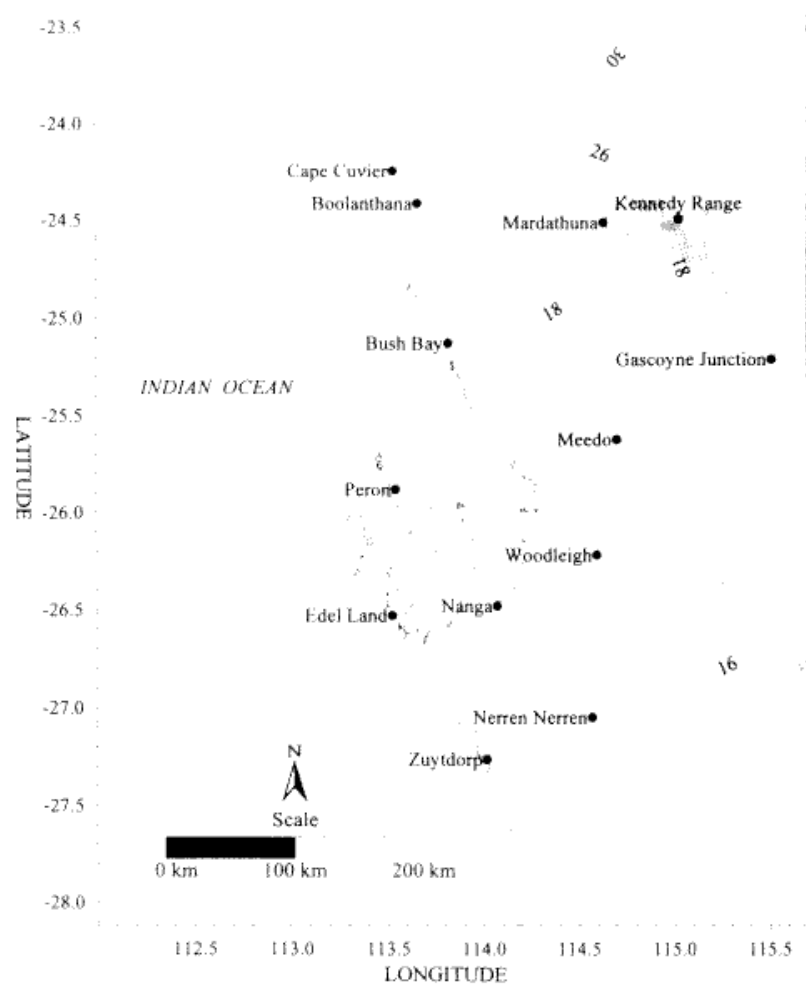

Figure A9 Mean temperature of wettest quarter.

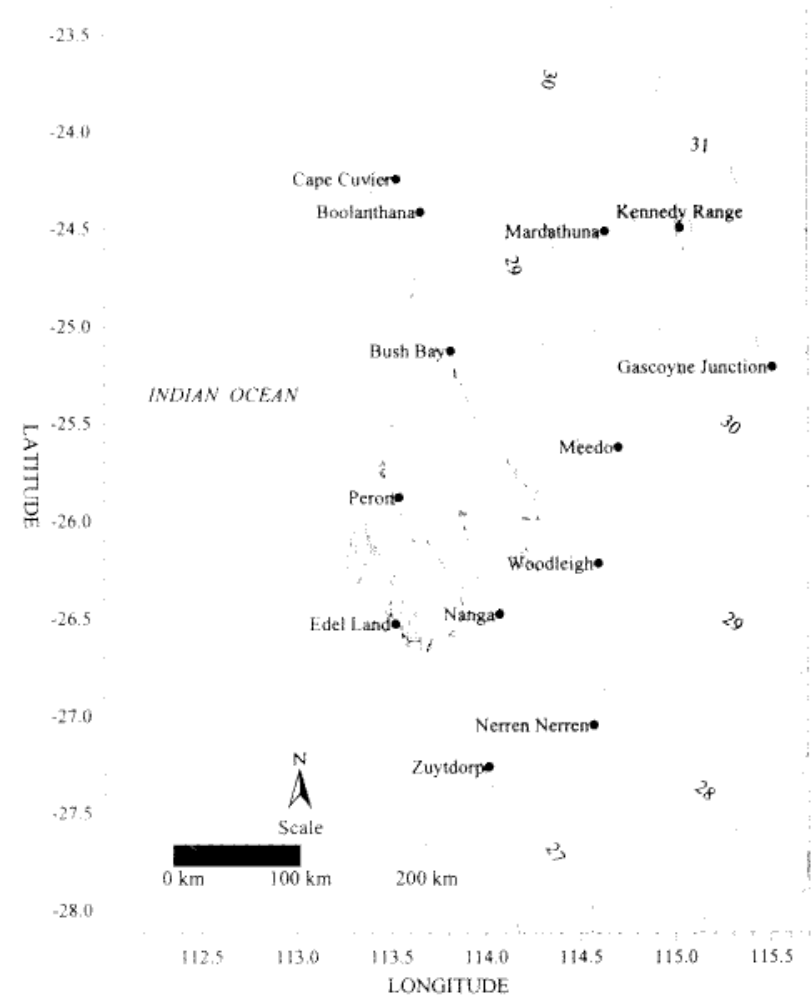

Figure A10 Mean temperature of warmest quarter.

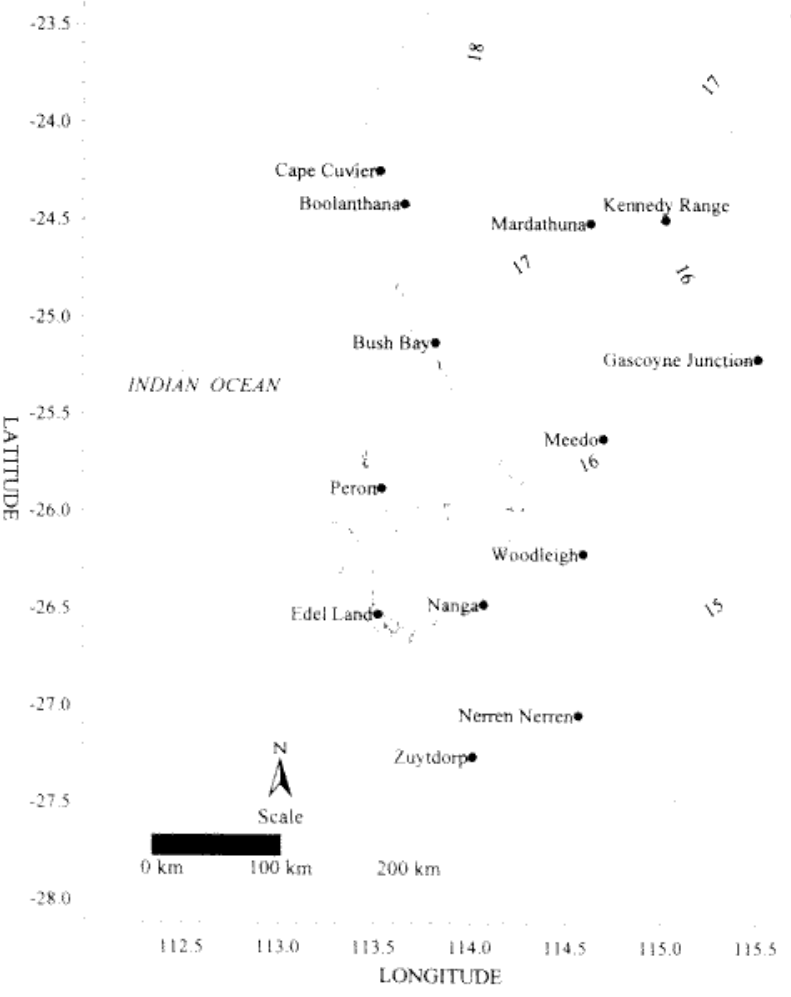

Figure A11 Mean temperature of coldest quarter. 